\title{
Utilization of Quarry Dust and Calcareous Fly Ash for the Production of Lightweight Cellular Micro-Concrete-Synthesis and Characterization
}

\author{
Athanasia Soultana * and Michael Galetakis \\ School of Mineral Resources Engineering, Technical University of Crete, 73100 Chania, Greece; \\ galetaki@mred.tuc.gr \\ * Correspondence: asoultana@isc.tuc.gr
}

Received: 27 October 2020; Accepted: 23 November 2020; Published: 25 November 2020

\begin{abstract}
This study aims to assess the production of cellular micro-concrete, consisting of quarry dust, calcareous fly ash, cement, and aluminum powder as aerating agent. The proposed mixture design methodology is based on a Box-Behnken fractional factorial experimental design. Testing of specimens included compressive and flexural strength, density, water absorption, and thermal conductivity measurements. Results indicate that density is a characteristic property which determines all the measured properties. Aerating agent to cement and fly ash ratio has the strongest effect on all the measured properties. The developed methodology is a valuable tool for the production of cellular micro-concrete with predetermined properties by utilizing large amounts of quarry dust.
\end{abstract}

Keywords: quarry dust; calcareous fly ash; cellular micro-concrete; Box-Behnken factorial design

\section{Introduction}

Aggregate quarrying operations such as crushing, sieving, etc., are used to produce large quantities of fine by-products $(<63 \mu \mathrm{m})$ known as quarry dust [1]. These fine by-products are difficult to handle and pose several environmental, health, and operational issues [2,3].

Disposal of quarry dust is one of the most critical problems facing the quarrying industry, since, on a number of occasions, quarry dust landfills may involve more space than the total of quarrying operations [4]. Using a large amount of quarry dust in construction applications could be a feasible solution to this problem, leading to both economic and environmental benefits for the quarrying sector. Even though there have been various proposed methods for the utilization of these by-products, they still remain under-utilized [1].

Over the past few years, there have been made many research efforts concerning the utilization of quarry dust as sand substitution material (partial or total replacement) for the production of several types of concrete and building elements [1,3-14]. However, the usage of quarry dust in these applications is rather demanding with regard to compositional aspects. More specifically, partial replacement of sand by quarry dust (up to $20 \%$ replacement) for the production of concrete and cement-based products improves the mechanical and durability properties, but the addition of higher quantities of quarry dust raises the water demand of the mixture. The large surface area of fines increases the water required in order to maintain proper workability of the mixture, resulting in higher shrinkage and strength deterioration [15]. However, the usage of effective superplasticizers, which reduce the required water amount, and sophisticated mixture design methodologies makes the incorporation of quarry dust in concrete and cement-based building elements possible [8].

Galetakis and Soultana [8] showed that the majority of research studies related to the exploitation of quarry dust as raw material in the construction sector refer to the production of self-compacting concrete 
and ordinary concrete products, while some of them study the production of cement-based building elements like masonry bricks and artificial stones (Figure 1). On the other hand, research studies related to the use of quarry dust for the production of lightweight structural elements such as aerated concrete are very limited [4-8].

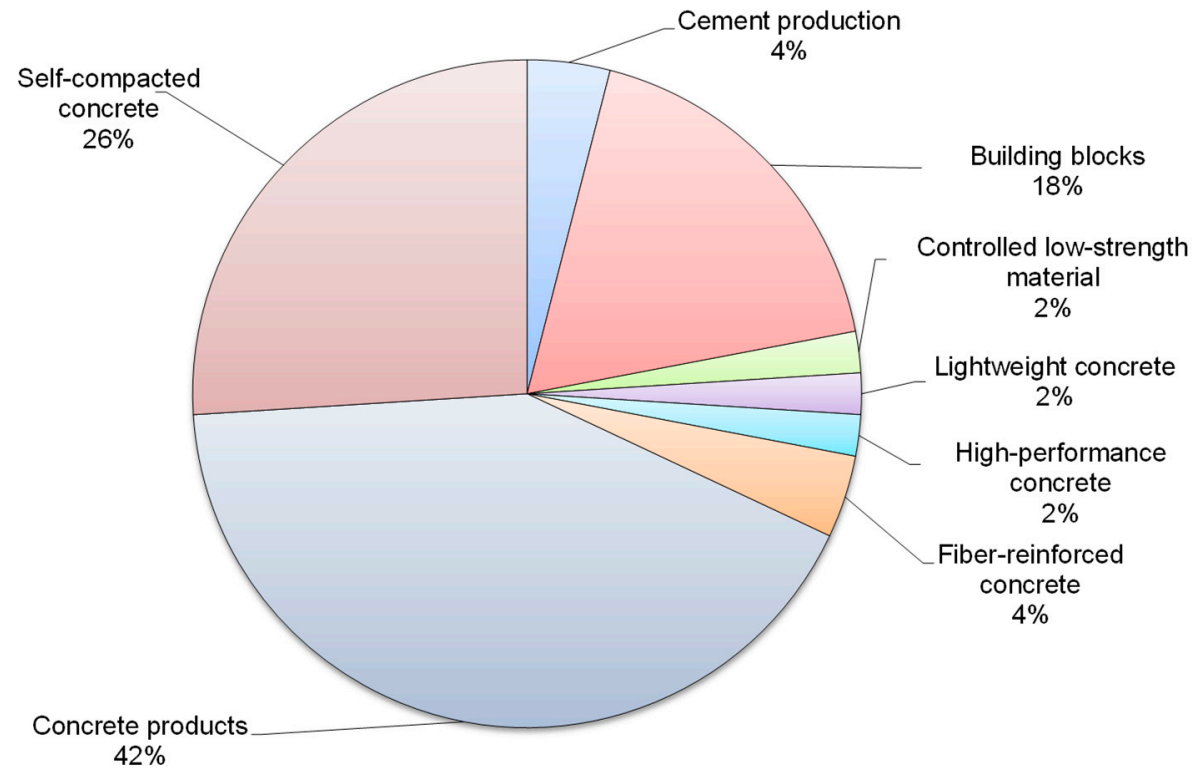

Figure 1. Proposed uses of quarry by-products. Based on Galetakis and Soultana [8].

Aerated concrete is a lightweight cellular material consisting of ultrafine aggregates (finely crushed quartz sand) and is therefore called cellular micro-concrete (CMC). Besides finely ground quartz sand, cement, lime, and a small amount of aluminum powder as aerating agent are also used for its production. It is homogeneous compared to conventional concrete, with a significantly lower density. It also has high workability and excellent thermal insulating properties [16].

Its cellular structure (Figure 2) is obtained through a gas-producing chemical reaction, as shown in Equation (1). The mechanism of the hydrogen-generating reaction takes place in four stages and includes the destruction of the passive layer at the surface of aluminum powder, the formation of katoite crystals, aluminum hydration, and the release of hydrogen [17]. Following the reaction, CMC can be cured under hydrothermal conditions at $180-200{ }^{\circ} \mathrm{C}$ using high-pressure steam (autoclaved) or moist-cured (non-autoclaved) [7,16].

$$
2 \mathrm{Al}+3 \mathrm{Ca}(\mathrm{OH})_{2}+6 \mathrm{H}_{2} \mathrm{O} \rightarrow 3 \mathrm{CaO} \cdot \mathrm{Al}_{2} \mathrm{O}_{3} \cdot 6 \mathrm{H}_{2} \mathrm{O}+3 \mathrm{H}_{2} \text { (gas) }
$$

Although the autoclaving process gives rise to crystallization and thus high compressive strength early on, this process is energy-intensive (typically reaching a temperature of $180-200^{\circ} \mathrm{C}$ and a pressure of $4-16$ bar) and requires a large amount of quartz sand that must be finely ground. Crushing quartz sand, as well as curing CMC, using autoclaving processes, is energy-intensive, so it is important to study the possibility of producing CMC by using other materials instead of quartz sand and less energy-intensive production procedures. Moreover, the fine-grained airborne quartz dust (also known as respirable crystalline silica in occupational hygiene) is a harmful substance if inhaled by humans [18]. Thus, its substitution by an inert substance, such as a quarry dust consisting mainly of calcite, is highly desirable.

Fly ash produced by lignite combustion for the production of electricity is also an important by-product. It is derived from coal-fired power stations, it has pozzolanic and/or hydraulic properties, and its composition is defined as a calcium-alumino-silicate. The use of fly ash can improve many properties of fresh and hardened concrete and contribute to lower energy consumption and reduced $\mathrm{CO}_{2}$ 
emissions $[19,20]$. In particular, the addition of siliceous fly ash improves workability, increases plasticity, and reduces water demand of the mixture, due to its fineness and the spherical shape of its grains [21]. However, a siliceous fly ash replacement of cement greater than $20 \%$ to $30 \%$ results in a reduction in the mechanical strength of the produced mixtures, especially at early stages due to the reduction in the pozzolanic activity of the mixture $[19,21]$. On the other hand, the addition of calcareous fly ash leads to reduced workability and higher water demand, but it also enhances mechanical strength at early stages [22,23]. Calcareous fly ashes are rich in free lime and so it is estimated that they can be used for the total substitution of lime, which is used in $\mathrm{CMC}$ production using $\mathrm{Al}$ powder as an aerating agent.

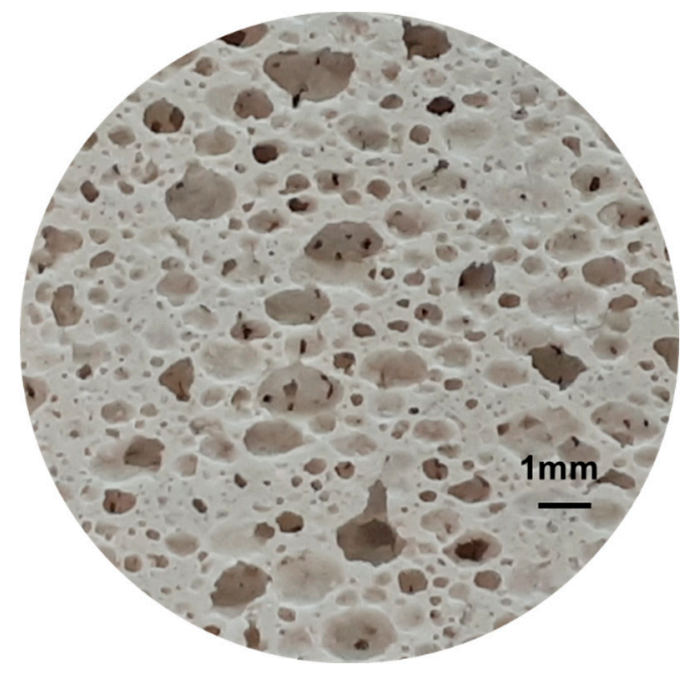

Figure 2. Porous structure of CMC.

This study aims to assess the simultaneous use of calcareous fly ash and quarry dust for the production of CMC. More specifically, it aims to assess the production of CMC optimized for strength and density, consisting of cement, calcareous fly ash, and high amounts of quarry dust under the conventional curing process used for cement-based building elements (at $20 \pm 2{ }^{\circ} \mathrm{C}$ and a relative humidity of at least $95 \%$ for 28 days). The achievement of optimal values of strength and density is challenging; thus, a specialized mixture design methodology based on the Box-Behnken fractional factorial design of experiments is proposed.

Factorial design of experiments is widely used for product optimization in several manufacturing processes [24-28]. The most common factorial designs used in optimization are the three-level full factorial design, the central composite designs (CCD), and the Box-Behnken (BB) designs. Full three-level factorial design requires a large number of experiments when dealing with a great number of factors. In such cases, a subset of full factorial design, referred to as fractional factorial design, is used. The Box-Behnken design used in this study is a three-level fractional factorial design and constitutes a quick and cost-effective method to study the joint effect of design factors with the minimum number of experiments [29]. Readers interested in factorial design of experiments could refer to [30].

\section{Materials and Methods}

\subsection{By-Product Characterization}

Quarry dust used in this study comes from a dry mortar plant located in the island of Crete (Chania, Greece). More specifically, it was collected through the de-dusting process of mortar-grade crushed marble sand by post dryer air cyclones. Calcareous fly ash originates from a coal power plant located at Agios Dimitrios in Kozani area (Kozani, Greece). 
Both fly ash and quarry dust were characterized for their particle size distribution and their mineralogical composition. Particle size was determined by a laser particle size analyzer (Malvern Instruments, Mastersize-S, Malvern, UK). Mineralogical analysis was performed using an X-ray diffractometer (Bruker AXS, D8-Advance, Billerica, MA, USA) with a Cu tube and a scanning range from $4^{\circ}$ to $70^{\circ} 2$-theta $(\theta)$, with a step $0.02^{\circ}$ and $0.2 \mathrm{~s} /$ step measuring time.

The grain size distribution of the quarry dust and the fly ash used is shown in Figure 3. As seen in Figure 3, the median particle size for quarry dust and fly ash is 48 and $20 \mu \mathrm{m}$, respectively.

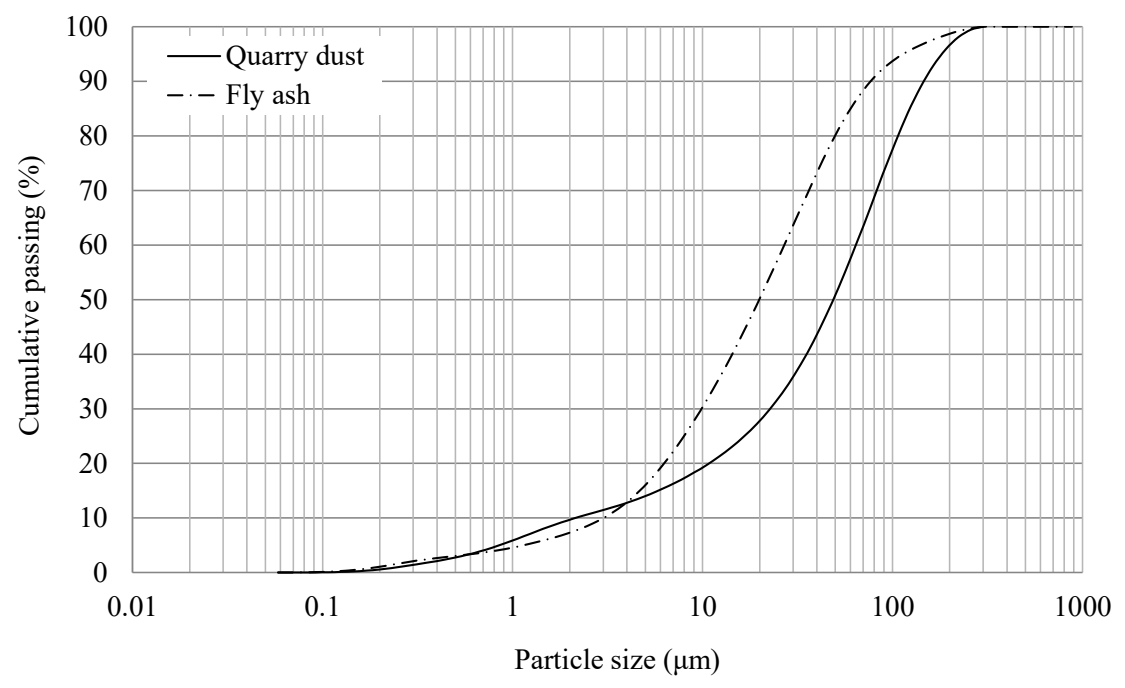

Figure 3. Particle size distribution of quarry dust and fly ash used.

Regarding quarry dust, mineralogical analysis (Figure 4) showed that it consists of $97 \%$ calcite $\left(\mathrm{CaCO}_{3}\right), 2 \%$ dolomite $\left(\mathrm{CaMg}\left(\mathrm{CO}_{3}\right)_{2}\right)$, and $1 \%$ quartz $\left(\mathrm{SiO}_{2}\right)$.

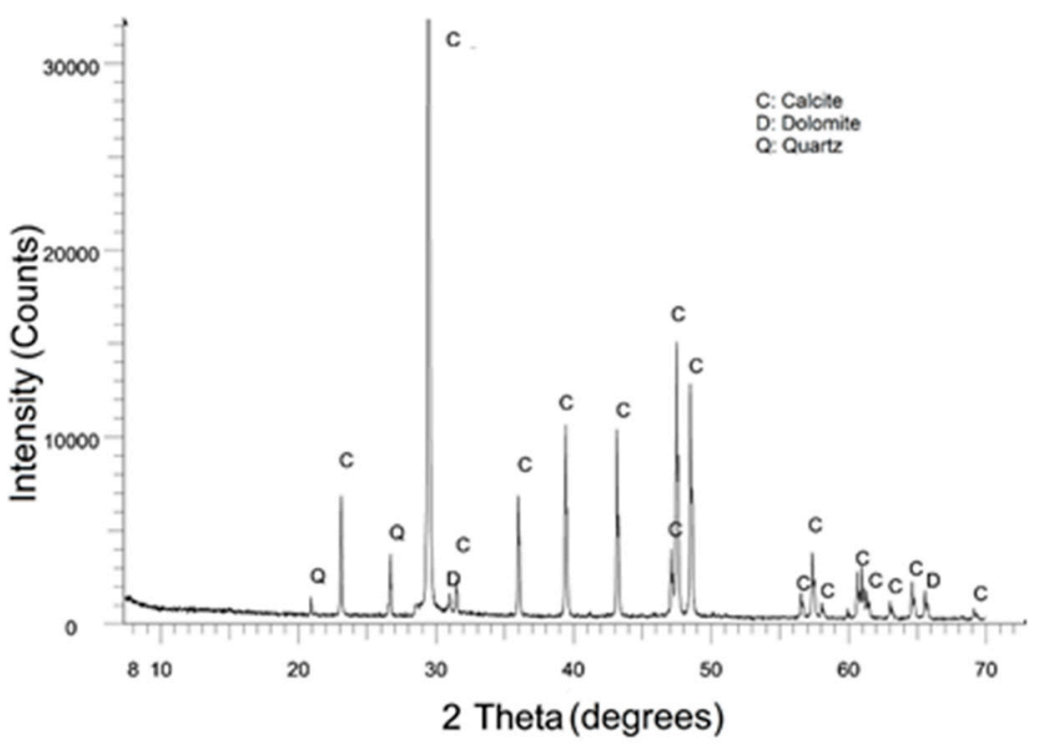

Figure 4. XRD pattern of quarry dust.

Figure 5 and Table 1 present the XRD pattern and the mineralogical composition of the fly ash used, respectively. As seen in Table 1 and Figure 5, fly ash contains a high amount of $\mathrm{CaO}(22 \%)$ as free lime and so it can be used for the total substitution of lime for the production of CMC. 


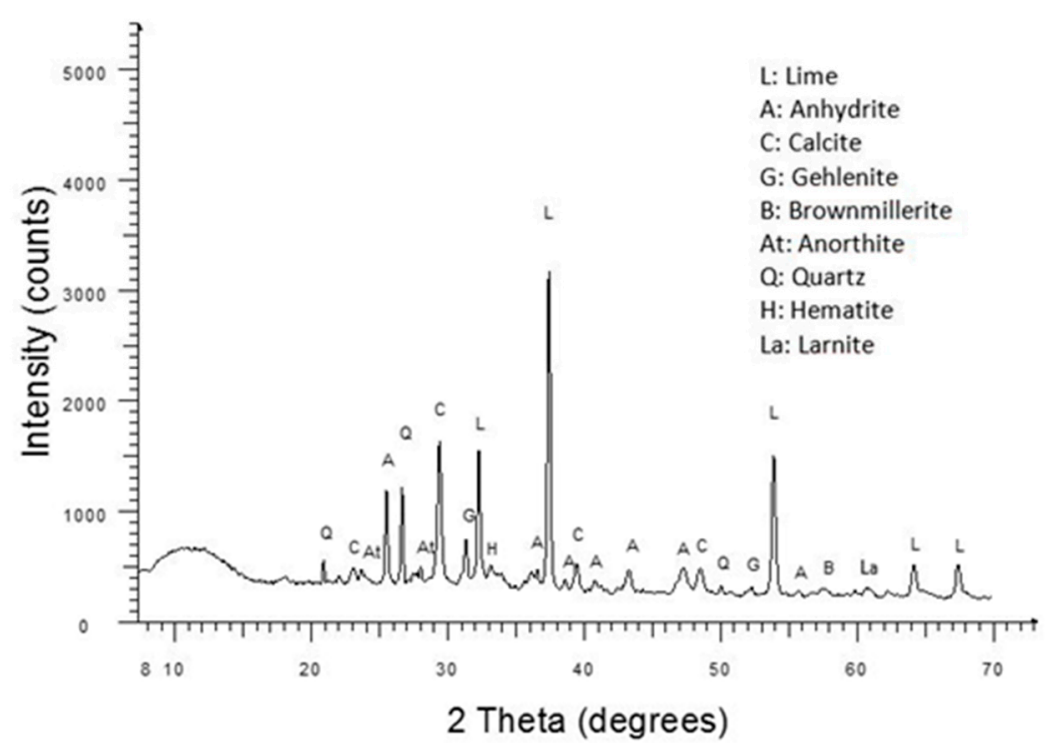

Figure 5. XRD pattern of fly ash.

Table 1. Mineralogical composition of fly ash.

\begin{tabular}{cc}
\hline Mineral & $\mathbf{w t} \%$ \\
\hline L: Lime, $\mathrm{CaO}$ & 22 \\
A: Anhydrite, $\mathrm{CaSO}_{4}$ & 7 \\
C: Calcite, $\mathrm{CaCO}_{3}$ & 24 \\
B: Brownmillerite, $\mathrm{Ca}_{2}(\mathrm{Al}, \mathrm{Fe})_{2} \mathrm{O}_{5}$ & 7 \\
Q: Quartz, $\mathrm{SiO}_{2}$ & 7 \\
G: Gehlenite, $\mathrm{Ca}_{2} \mathrm{Al}_{2} \mathrm{SiO}_{7}$ & 4 \\
At: Anorthite, $\mathrm{CaAl}_{2} \mathrm{Si}_{2} \mathrm{O}_{8}$ & 6 \\
H: Hematite, $\mathrm{Fe}_{2} \mathrm{O}_{3}$ & 1 \\
La: Larnite, $\mathrm{Ca}_{2} \mathrm{SiO}_{4}$ & 2 \\
Amorphous $\mathrm{material}$ & 20 \\
\hline
\end{tabular}

\subsection{Cement Type and Admixtures}

In this study, ordinary Portland cement type CEM I 42.5N complying with EN 197-1 was used in various proportions. In order to reduce the water demand and improve the rheological characteristics of the mixture, a polycarboxylate-based superplasticizer type Melflux $2651 \mathrm{~F}$ was also used. A limestone-aluminum mixture type RO 260 composed of $10 \%$ aluminum powder and $90 \%$ limestone powder was used as an aerating agent in various proportions. The aerating agent used had an average diameter of around $45 \mu \mathrm{m}$ and a high specific surface area $\left(\sim 19,000 \mathrm{~cm}^{2} / \mathrm{g}\right)$.

\subsection{Mixture Design Methodology}

At first, the ingredient proportions and admixture dosages were chosen based on a series of preliminary tests, where material availability, economic, technical, and environmental factors, as well as existing studies were taken into consideration $[1,8,23,31]$. More specifically, cement proportions were chosen to vary between 12 and $22 \mathrm{wt} \%$, fly ash proportions ranged from 8 to $15 \mathrm{wt} \%$, quarry dust ranged between 31 and $53 \mathrm{wt} \%$, while aerating agent and superplasticizer dosages were chosen based on the manufacturer's recommendations and varied between 1.3 and $3 \mathrm{wt} \%$ and between 0.08 and $0.16 \mathrm{wt} \%$, respectively.

As already mentioned in Section 2.1, the fly ash used contains a high amount of $\mathrm{CaO}(22 \%)$, which leads to the fast setting of the mixtures and higher water demand [22,23]. For a given mixing and molding time, fast setting of the mixtures requires higher amounts of water in order to maintain the slurry properties. For this reason, a SOWER high speed mixer (0-8000 rpm) was used for the 
production of the mixtures in order to achieve short mixing time (20-40 s), reduce the required water content, and achieve high grain dispersion. The rpm experimentation range was chosen based on a series of preliminary tests where the desired flowability of the mixture measured by the micro-cone spread test and the required water-to-solids ratio were taken into consideration. Tests showed that the rpm of the mixer should be preferably among 3000-5000. For the chosen mixing time, more than $5000 \mathrm{rpm}$ results in less workable mixtures due to the increased number of revolutions [32].

Subsequently, after the range of the proportions of the ingredients in the mixtures was estimated, the Box-Behnken fractional factorial design of experiments was used to estimate the effect of synthesis parameters and mixing speed on the properties of the produced CMC $[8,33]$. Factorial design of experiments allows an experimenter to make intentional changes to the design parameters (also called factors) of a process in order to identify and observe the changes that occur to the response variables.

In this study, four factors were considered:

- $\quad$ Cement and fly ash to quarry dust ratio (CFA/D);

- $\quad$ Aerating agent to cement and fly ash ratio (Al/CFA);

- $\quad$ Superplasticizer (wt\%) (SPL);

- $\quad$ Revolutions per minute (rpm) of the mixer (RPM).

Following the standard notation used in factorial design, the above factors were also coded as $\mathrm{A}$, $B, C$, and D, respectively.

The examined response variables included the water-to-solids ratio $(\mathrm{w} / \mathrm{s})$ of the fresh mixture and the compressive strength $\left(\mathrm{F}_{\mathrm{c}}\right)$, flexural strength $\left(\mathrm{F}_{\mathrm{f}}\right)$, density $(\mathrm{d})$, water absorption $\left(\mathrm{W}_{\mathrm{a}}\right)$, and thermal conductivity $(\lambda)$ of hardened specimens.

Each design parameter was tested at three levels, low, medium, and high, coded as $-1,0,1$, respectively. The selected levels of design parameters are given in Table 2.

A full factorial experimental design of 4 factors with 3 levels of experimentation would result in $81\left(3^{4}\right)$ mixtures, while a Box-Behken fractional design using a subset of a full factorial design leads to 25 mixtures. For the calculation of the measurement error, the middle level (0) is repeated three times. Thus, a total of 27 mixtures were finally prepared and tested. The resulting combinations are shown in Table 2. Table 2 also contains the design parameters of a reference mixture which was prepared without the addition of aerating agent.

Box-Behnken design allows the development of an adequate model relating a response variable $y$ and the associated $k$ design parameters denoted by $x_{1}, x_{2}, \ldots, x_{k}$ by using the response surface methodology. The developed model can be used to find optimum settings of $x_{i}$ that result in the maximum or minimum response $y$ over a region of interest. Box-Behnken factorial design of experiments uses three levels of experimentation for each design parameter and requires significantly smaller number of experiments compared to full factorial design of experiments. It is widely used for the development of second order polynomial models for relating a response variable $y$ and the associated design parameters $x_{i}[33,34]$.

$$
y=b_{0}+\sum_{i=1}^{k} b_{i} x_{i}+\sum_{i \neq j} b_{i j} x_{i} x_{j}+\sum_{i=1}^{k} b_{i i} x_{i}^{2}+\varepsilon
$$

where $b_{0}$ is the constant term, $b_{i}$ and $b_{i i}$ are the first and second order coefficients, respectively, $b_{i j}$ are the coefficients for the interactions $x_{i} x_{j}$, and $\varepsilon$ is the prediction error. 
Table 2. Parameters and levels of design, mixtures prepared according to Box-Behnken factorial design, and raw material proportions.

\begin{tabular}{|c|c|c|c|c|c|c|c|c|c|c|}
\hline \multirow{2}{*}{$\begin{array}{c}\text { Mixture } \\
\text { No. }\end{array}$} & \multicolumn{4}{|c|}{ Design Parameters * } & \multicolumn{6}{|c|}{ Raw Materials Proportions $\left(\mathrm{kg} / \mathrm{m}^{3}\right)$} \\
\hline & $\mathbf{A}$ & B & $\mathrm{C}$ & $\mathbf{D}$ & $\begin{array}{l}\text { Fly } \\
\text { Ash }\end{array}$ & $\begin{array}{l}\text { CEM I } \\
42.5 \mathrm{~N}\end{array}$ & $\begin{array}{c}\text { Quarry } \\
\text { Dust }\end{array}$ & $\begin{array}{c}\text { Aerating } \\
\text { Agent }\end{array}$ & Superplasticizer & Water \\
\hline 1 & 0.430 & 0.075 & 0.000 & 4000 & 140 & 210 & 817 & 26 & 0.00 & 370 \\
\hline 2 & 0.715 & 0.075 & 0.125 & 4000 & 173 & 255 & 592 & 32 & 1.32 & 379 \\
\hline 3 & 1.000 & 0.075 & 0.125 & 3000 & 195 & 293 & 489 & 37 & 1.27 & 422 \\
\hline 4 & 0.715 & 0.075 & 0.125 & 4000 & 173 & 255 & 592 & 32 & 1.32 & 379 \\
\hline 5 & 0.715 & 0.050 & 0.125 & 5000 & 174 & 256 & 593 & 21 & 1.31 & 388 \\
\hline 6 & 0.430 & 0.075 & 0.125 & 3000 & 126 & 190 & 737 & 24 & 1.35 & 351 \\
\hline 7 & 0.715 & 0.050 & 0.000 & 4000 & 196 & 288 & 667 & 24 & 0.00 & 388 \\
\hline 8 & 0.715 & 0.075 & 0.125 & 4000 & 173 & 255 & 592 & 32 & 1.32 & 379 \\
\hline 9 & 0.715 & 0.100 & 0.125 & 3000 & 173 & 254 & 590 & 43 & 1.33 & 370 \\
\hline 10 & 1.000 & 0.075 & 0.000 & 4000 & 218 & 327 & 546 & 41 & 0.00 & 430 \\
\hline 11 & 1.000 & 0.075 & 0.250 & 4000 & 184 & 276 & 460 & 34 & 2.39 & 370 \\
\hline 12 & 0.430 & 0.075 & 0.250 & 4000 & 117 & 176 & 685 & 22 & 2.50 & 313 \\
\hline 13 & 0.430 & 0.100 & 0.125 & 4000 & 125 & 188 & 732 & 31 & 1.35 & 351 \\
\hline 14 & 0.715 & 0.075 & 0.250 & 5000 & 158 & 233 & 541 & 29 & 2.40 & 361 \\
\hline 15 & 0.430 & 0.050 & 0.125 & 4000 & 127 & 191 & 743 & 16 & 1.35 & 351 \\
\hline 16 & 0.715 & 0.100 & 0.250 & 4000 & 161 & 236 & 548 & 40 & 2.46 & 332 \\
\hline 17 & 0.715 & 0.100 & 0.125 & 5000 & 172 & 252 & 586 & 42 & 1.32 & 379 \\
\hline 18 & 1.000 & 0.050 & 0.125 & 4000 & 199 & 299 & 498 & 25 & 1.28 & 414 \\
\hline 19 & 1.000 & 0.075 & 0.125 & 5000 & 200 & 300 & 500 & 37 & 1.30 & 396 \\
\hline 20 & 0.715 & 0.050 & 0.250 & 4000 & 164 & 241 & 559 & 20 & 2.46 & 332 \\
\hline 21 & 0.715 & 0.075 & 0.000 & 3000 & 194 & 285 & 661 & 36 & 0.00 & 388 \\
\hline 22 & 0.715 & 0.100 & 0.000 & 4000 & 187 & 276 & 640 & 46 & 0.00 & 414 \\
\hline 23 & 0.715 & 0.050 & 0.125 & 3000 & 171 & 252 & 584 & 21 & 1.29 & 405 \\
\hline 24 & 0.715 & 0.075 & 0.250 & 3000 & 161 & 237 & 549 & 30 & 2.44 & 342 \\
\hline 25 & 0.715 & 0.075 & 0.000 & 5000 & 195 & 287 & 666 & 36 & 0.00 & 379 \\
\hline 26 & 0.430 & 0.075 & 0.125 & 5000 & 124 & 187 & 726 & 23 & 1.33 & 370 \\
\hline 27 & 1.000 & 0.100 & 0.125 & 4000 & 196 & 294 & 490 & 49 & 1.29 & 405 \\
\hline Reference & 0.715 & 0.000 & 0.125 & 4000 & 175 & 257 & 597 & 0 & 1.29 & 405 \\
\hline \multicolumn{8}{|c|}{ * Levels of design: } & Low $(-1)$ & Medium (0) & High $(+1)$ \\
\hline \multicolumn{8}{|c|}{ CFA/D (A): Cement and fly ash to quarry dust ratio } & 0.430 & 0.715 & 1.000 \\
\hline \multicolumn{8}{|c|}{$\mathrm{Al} / \mathrm{CFA}(\mathrm{B})$ : Aerating agent to cement and fly ash ratio } & 0.050 & 0.075 & 0.100 \\
\hline \multicolumn{8}{|c|}{ SPL (C): Superplasticizer (wt $\%)$} & 0.000 & 0.125 & 0.250 \\
\hline \multicolumn{8}{|c|}{ RPM (D): Revolutions per minute (rpm) of the mixer } & 3000 & 4000 & 5000 \\
\hline
\end{tabular}

\subsection{Specimen Preparation and Testing}

Quarry dust was dry mixed with cement, fly ash, superplasticizer, and aerating agent. Then, water was added to the dry mixture gradually until the mixture obtained the required flowability measured by the micro-cone spread test, and water-to-solids ratio was calculated. The micro-cone spread test is a modified version of the flow cone test EN 11041, which measures the flowability of fresh micro-concrete [31]. Micro-cone spread diameter was calculated as a mean value of three micro-cone spread measurements regarding the reference mixture and was used as a reference value for the produced mixtures. The measured spread cone diameter was $12.7 \mathrm{~cm}$. Accepted micro-cone spread test values ranged between 12 and $13 \mathrm{~cm}$. Mixture proportions are indicated in Table 2.

Following mixing procedure, fresh mixture was poured into prismatic molds $\left(4 \times 4 \times 16 \mathrm{~cm}^{3}\right)$ and was left for $24 \mathrm{~h}$ to expand, to form its cellular structure, and to achieve the hardening required for the demolding (Figure 6a,b). The produced specimens were then cured for 28 days in a Matest E139 curing chamber (at $20 \pm 2{ }^{\circ} \mathrm{C}$ and a relative humidity of at least 95\%) according to EN 196-1. 


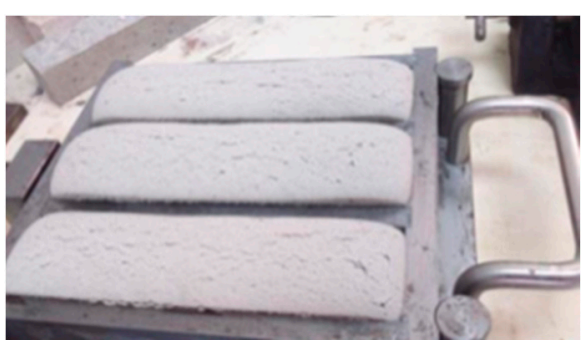

(a)

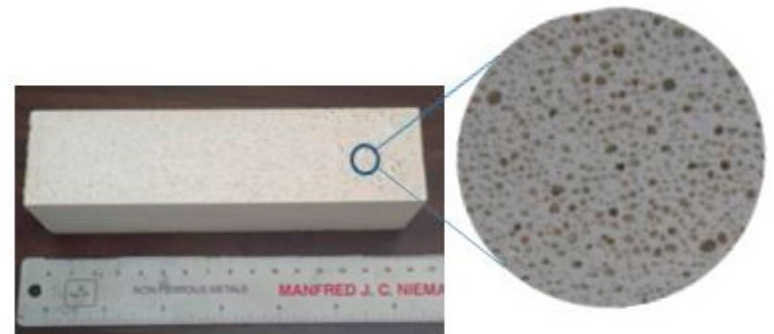

(b)

Figure 6. (a) Mixtures cast into $40 \times 40 \times 160 \mathrm{~mm}^{3}$ molds after aeration; (b) specimen with flattened surface.

For each hardened specimen, the compressive and flexural strength, dry density, water absorption, and thermal conductivity were measured.

Measurement of compressive $\left(\mathrm{F}_{\mathrm{c}}\right)$ and flexural $\left(\mathrm{F}_{\mathrm{f}}\right)$ strength was performed according to EN 196-1 using a Matest E161-03N compression and flexural machine with dual range 500/15 kN. For each mixture, 3 specimens were produced and tested, and compressive and flexural strength values were calculated as their average.

Determination of thermal conductivity of specimens $(\lambda)$ was conducted according to radial heat flow method [35]. This method uses thermocouples to measure temperature difference at a specific distance when heat $Q$ flows through a sample. More specifically, a cylindrical sample is heated at the axis and the heat flows radially outwards, as seen in Figure 7 . The thermal conductivity is given by Equation (3):

$$
\lambda=\frac{Q \ln \left(\frac{r_{2}}{r_{1}}\right)}{2 \pi h \Delta T}
$$

where $r_{1}$ and $r_{2}$ refer to the distance between the two thermocouples and the axis of the sample, $h$ is the height of the sample, and $\Delta \mathrm{T}$ is the temperature difference between the two thermocouples [35].

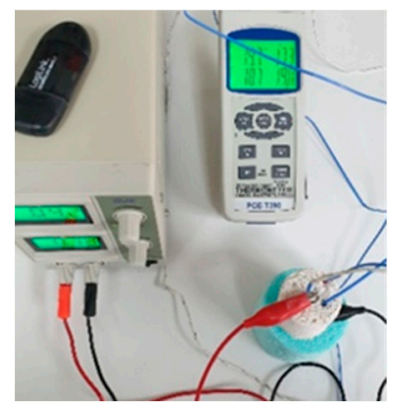

(a)

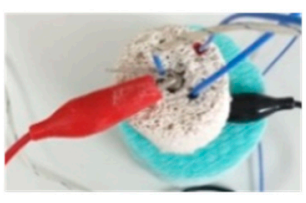

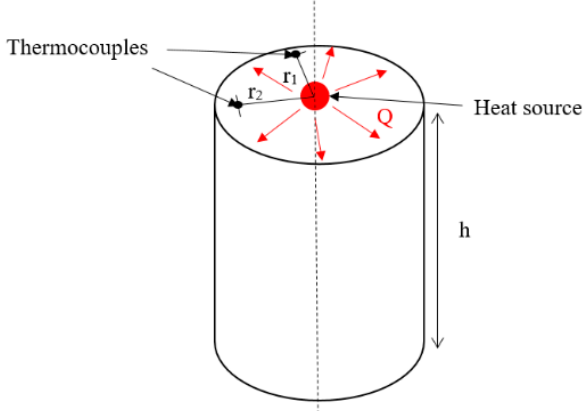

(b)

Figure 7. (a) Experimental setup for the measurement of thermal conductivity; (b) schematic of radial heat flow method. Based on Zhao et al. [35].

The measured cylindrical samples in this study were extracted from the hardened prismatic specimens using a diamond core drilling tool. The sample diameter was $35 \mathrm{~mm}$, the height $h$ was $40 \mathrm{~mm}$, and the distances between the two thermocouples and the axis of the sample $r_{1}$ and $r_{2}$ were 8 and $12 \mathrm{~mm}$, respectively. Thermal conductivity measurements were conducted under stable ambient conditions at $21 \pm 1^{\circ} \mathrm{C}$. 


\section{Analysis of Results and Discussion}

The results of factorial design are given in Table 3 and show the mixtures' design parameters (A, $B, C, D)$ along with the selected response variables $\left(w / s, d, F_{c}, F_{f}, W_{a}\right.$, and $\left.\lambda\right)$. The density $d$ of the hardened specimens varies from 680 to $1080 \mathrm{~kg} / \mathrm{m}^{3}$ and is considerably lower compared to the reference $\left(1530 \mathrm{~kg} / \mathrm{m}^{3}\right)$ that was prepared without the addition of the aerating agent. This decrease in density affected physical and mechanical properties of the produced cellular micro-concrete (CMC) significantly.

Table 3. Box-Behnken factorial design and test results.

\begin{tabular}{|c|c|c|c|c|c|c|c|c|c|c|}
\hline \multirow{2}{*}{$\begin{array}{c}\text { Mixture } \\
\text { No. }\end{array}$} & \multicolumn{4}{|c|}{ Design Parameters } & \multicolumn{6}{|c|}{ Response Variables } \\
\hline & $\mathbf{A}$ & B & $\mathrm{C}$ & D & w/s & $\underset{\left(\mathrm{kg} / \mathrm{m}^{3}\right)}{d}$ & $\begin{array}{c}F_{\mathrm{c}} \\
(\mathrm{MPa})\end{array}$ & $\begin{array}{c}\mathrm{F}_{\mathrm{f}} \\
(\mathrm{MPa})\end{array}$ & $\begin{array}{c}\lambda \\
(W / m \cdot K)\end{array}$ & $\begin{array}{l}W_{a} \\
(\%)\end{array}$ \\
\hline 1 & 0.430 & 0.075 & 0.000 & 4000 & 0.31 & 780 & 2.8 & 2.6 & 0.20 & 37.2 \\
\hline 2 & 0.715 & 0.075 & 0.125 & 4000 & 0.32 & 870 & 3.9 & 3.3 & 0.24 & 32.3 \\
\hline 3 & 1.000 & 0.075 & 0.125 & 3000 & 0.37 & 770 & 4.3 & 2.6 & 0.24 & 37.3 \\
\hline 4 & 0.715 & 0.075 & 0.125 & 4000 & 0.32 & 900 & 4.0 & 3.4 & 0.25 & 31.1 \\
\hline 5 & 0.715 & 0.05 & 0.125 & 5000 & 0.33 & 950 & 5.3 & 3.5 & 0.30 & 30.1 \\
\hline 6 & 0.430 & 0.075 & 0.125 & 3000 & 0.29 & 920 & 4.3 & 3.2 & 0.27 & 30.7 \\
\hline 7 & 0.715 & 0.050 & 0.000 & 4000 & 0.33 & 890 & 3.8 & 3.1 & 0.24 & 32.2 \\
\hline 8 & 0.715 & 0.075 & 0.125 & 4000 & 0.32 & 910 & 4.7 & 3.4 & 0.29 & 31.4 \\
\hline 9 & 0.715 & 0.100 & 0.125 & 3000 & 0.31 & 900 & 4.2 & 3.3 & 0.28 & 30.3 \\
\hline 10 & 1.000 & 0.075 & 0.000 & 4000 & 0.38 & 690 & 2.4 & 1.9 & 0.18 & 45.1 \\
\hline 11 & 1.000 & 0.075 & 0.250 & 4000 & 0.31 & 900 & 6.4 & 3.4 & 0.28 & 31.9 \\
\hline 12 & 0.430 & 0.075 & 0.250 & 4000 & 0.25 & 930 & 5.5 & 3.3 & 0.28 & 30.4 \\
\hline 13 & 0.430 & 0.100 & 0.125 & 4000 & 0.29 & 930 & 3.4 & 3.0 & 0.25 & 30.6 \\
\hline 14 & 0.715 & 0.075 & 0.250 & 5000 & 0.30 & 860 & 6.1 & 3.8 & 0.24 & 33.8 \\
\hline 15 & 0.430 & 0.050 & 0.125 & 4000 & 0.29 & 1030 & 6.3 & 3.4 & 0.33 & 26.3 \\
\hline 16 & 0.715 & 0.100 & 0.250 & 4000 & 0.27 & 970 & 6.3 & 4.2 & 0.28 & 28.5 \\
\hline 17 & 0.715 & 0.100 & 0.125 & 5000 & 0.32 & 860 & 4.9 & 3.3 & 0.23 & 34.2 \\
\hline 18 & 1.000 & 0.050 & 0.125 & 4000 & 0.36 & 810 & 4.3 & 2.7 & 0.22 & 34.8 \\
\hline 19 & 1.000 & 0.075 & 0.125 & 5000 & 0.34 & 860 & 6.7 & 2.8 & 0.23 & 33.5 \\
\hline 20 & 0.715 & 0.050 & 0.250 & 4000 & 0.27 & 1080 & 7.1 & 5.6 & 0.31 & 23.8 \\
\hline 21 & 0.715 & 0.075 & 0.000 & 3000 & 0.33 & 830 & 3.3 & 2.5 & 0.25 & 34.1 \\
\hline 22 & 0.715 & 0.100 & 0.000 & 4000 & 0.36 & 680 & 1.9 & 1.9 & 0.19 & 40.1 \\
\hline 23 & 0.715 & 0.050 & 0.125 & 3000 & 0.35 & 880 & 5.3 & 3.5 & 0.28 & 33.6 \\
\hline 24 & 0.715 & 0.075 & 0.250 & 3000 & 0.28 & 850 & 5.0 & 3.5 & 0.27 & 30.2 \\
\hline 25 & 0.715 & 0.075 & 0.000 & 5000 & 0.32 & 720 & 2.5 & 4.4 & 0.19 & 41.3 \\
\hline 26 & 0.430 & 0.075 & 0.125 & 5000 & 0.31 & 900 & 4.5 & 3.2 & 0.24 & 32.8 \\
\hline 27 & 1.000 & 0.100 & 0.125 & 4000 & 0.35 & 790 & 3.6 & 2.7 & 0.22 & 36.2 \\
\hline Reference & 0.715 & 0.000 & 0.125 & 4000 & 0.35 & 1530 & 25.8 & 7.4 & 0.49 & 18.1 \\
\hline
\end{tabular}

In order to determine the effect of synthesis parameters on the properties of the produced CMC specimens and to optimize mixture composition, results analysis was conducted in two stages. Firstly, measured physical and mechanical properties of fresh and hardened CMC specimens were correlated with density and compared to reference values, and secondly, the factorial experimentation was analyzed, and the modeling and optimization were performed.

Moreover, the physical and mechanical properties of the produced cellular micro-concrete were compared to those obtained by other researchers in previous studies [36-39].

\subsection{Correlation of Measured Properties}

Results of Table 3 indicate that the measured response variables $\left(d, F_{c}, F_{f}, W_{a}, \lambda\right.$ and w/s) for the hardened specimens are not independent but showed strong correlation. Figure 8 presents the correlation diagram between the measured response variables, while Table 4 gives the Pearson correlation coefficients for each pair of response variables. These correlation coefficients range between -1 and +1 and measure the strength of the linear relationship between the variables. From Figure 8 
and Table 4 , it can be seen that $d, F_{c}, F_{f}, W_{a}, \lambda$, and w/s are strongly correlated. Density (d) shows the higher correlation coefficients and can be considered as the most decisive response variable.

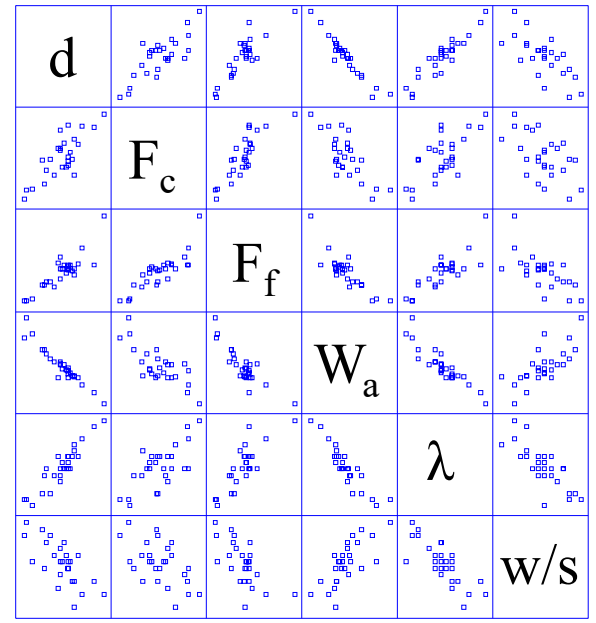

Figure 8. Correlation diagram between response variables $\left(d, F_{c}, F_{f}, W_{a}, \lambda\right.$, and w/s).

Table 4. Pearson correlation coefficients for each pair of response variables $\left(d, F_{c}, F_{f}, W_{a}\right.$, $\lambda$, and w/s).

\begin{tabular}{ccccccc}
\hline & $\mathbf{d}$ & $\mathbf{F}_{\mathbf{c}}$ & $\mathbf{F}_{\mathbf{f}}$ & $\mathbf{W}_{\mathbf{a}}$ & $\boldsymbol{\lambda}$ & $\mathbf{w} / \mathbf{s}$ \\
\hline $\mathrm{d}$ & 1.00 & 0.80 & 0.87 & -0.96 & 0.93 & -0.70 \\
$\mathrm{~F}_{\mathrm{c}}$ & 0.80 & 1.00 & 0.84 & -0.75 & 0.67 & -0.55 \\
$\mathrm{~F}_{\mathrm{f}}$ & 0.87 & 0.84 & 1.00 & -0.86 & -0.83 & -0.65 \\
$\mathrm{~W}_{\mathrm{a}}$ & -0.96 & -0.75 & -0.86 & 1.00 & -0.91 & 0.73 \\
$\lambda$ & 0.93 & 0.67 & 0.83 & -0.91 & 1.00 & -0.79 \\
$\mathrm{w} / \mathrm{s}$ & -0.70 & -0.55 & -0.65 & 0.73 & -0.79 & 1.00 \\
\hline
\end{tabular}

It is well known that density is related to the pore structure of CMC. Any change in the pore structure of CMC may influence the material properties significantly in relation to density. More specifically, an increase in the porosity of CMC results in lower density, which in turn decreases the mechanical strength, while thermal insulation is enhanced [40,41]. Analysis of the CMC pore structure was beyond the scope of this study. However, since porosity and density are highly correlated (as shown in Table 4 and Figure 8), density is considered as the characteristic physical property of produced CMC specimens which largely determines all the other examined response variables.

\subsection{Physical and Mechanical Properties of Produced CMC Compared to Reference Mixture}

Figure 9 presents the percentage change in $F_{c}, F_{f}, d, W_{a}$, and $\lambda$ for the three levels of aerating agent to cement and fly ash ratio $(0.05,0.075$, and 0.1$)$ compared to the reference mixture (no aerating agent addition). Percentage change in the response variables was chosen to be examined in relation to the aerating agent to cement and fly ash ratio since this ratio determines the degree of aeration. In this way, the aerating agent to cement and fly ash ratio has a significant effect on the density of the hardened specimens, which is a physical property of great importance since, as already mentioned above, it strongly affects all the measured properties.

As seen in Figure $9 a$, the decrease rate of $F_{c}$ compared to that of $F_{f}$, for the same d decrement, is significantly higher. More specifically, a decrease in d of around $39 \%$ causes an $\mathrm{F}_{\mathrm{c}}$ decrease of $80 \%$, whereas $\mathrm{F}_{\mathrm{f}}$ decreases by around $51 \%$, for an aerating agent to cement and fly ash ratio of 0.05 . Figure $9 \mathrm{~b}$ shows that the decrement of $d$ causes a significant increase in $W_{a}$. More specifically, a $50 \%$ decrease in $\mathrm{d}$ provokes a $\mathrm{W}_{\mathrm{a}}$ increase of $89 \%$, for an aerating agent to cement and fly ash ratio of 0.075 . On the other hand, it seems that the decrease rate of $d$ is similar to that of $\lambda$. 
From Figure 9a,b, it can be observed that the increase in aerating agent to cement and fly ash ratio from 0.075 to 0.1 does not cause any significant change in the measured properties. This can be attributed to the fact that the mixtures produced with higher aerating agent to cement and fly ash ratio have insufficient amounts of $\mathrm{CaO}$, which is related to the cement and fly ash content of the mixture. In this way, the produced mixtures do not have the required amount of $\mathrm{CaO}$ to react with the higher amount of aluminum powder and provoke further aeration.

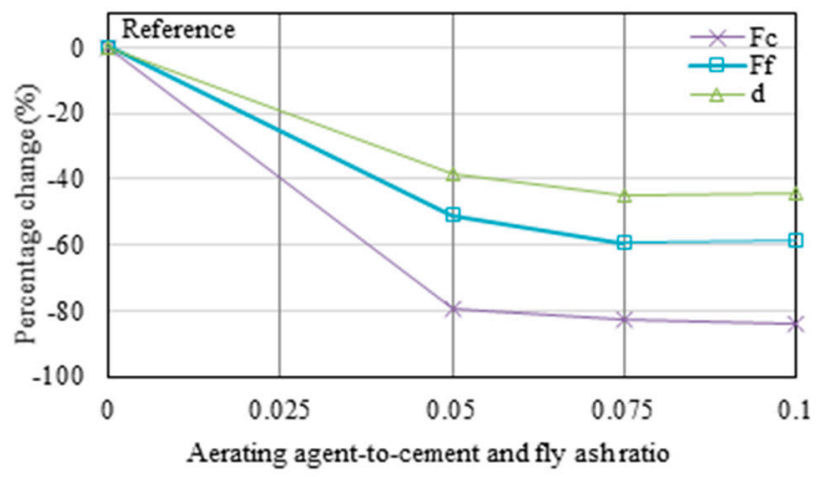

(a)

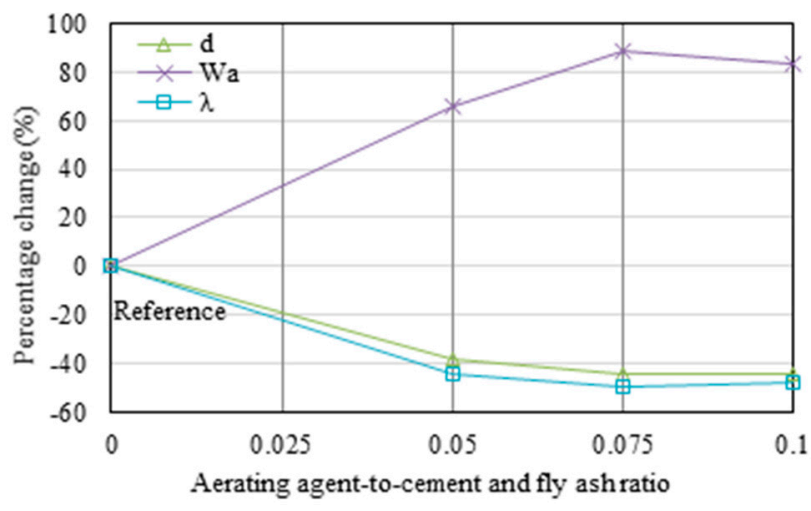

(b)

Figure 9. Percentage change in (a) $F_{c}, F_{f}$, and $d$; (b) $d, W_{a}$, and $\lambda$, for the three levels of aerating agent to cement and fly ash ratio $(0.05,0.075$, and 0.1$)$ compared to the reference mixture (no aerating agent addition).

\subsection{Factorial Design Analysis, Modeling, and Optimization}

The Box-Behnken factorial design results were analyzed according to the standard methodology proposed by Myers and Montgomery [33]. The conducted analysis included the calculation of main effects (first and second order) and interactions of design parameters (A, B, C, and D) on the response variables $\left(F_{c}, F_{f}, d, W_{a}, \lambda\right.$, and $\left.w / s\right)$ in order to identify those which have a significant effect on the response.

The first order main effect (factor) of a design parameter on a response variable is estimated as the difference between the response of a factor at the high level and at the low level, when all other factors are adjusted at their central values (midway between their low and high levels). The interactions between two factors express the additional effect of one factor, when the other one is held at its high level. Interactions occur when the effect of one factor is different at various levels of the other factor. Second order effects express the quadratic relationship between design parameters and response variables [42,43].

Next, the estimated effects were divided by the measurement error to obtain the standardized values. Standardized values, whose absolute value exceeded 1.96, were regarded as statistically 
significant. This value (1.96) results from the normal distribution at confidence level $95 \%$. After this, the statistically significant factors were used to develop second order polynomial models linking response variable with factors. Finally, the identification of the optimal design parameters was performed by using the response surface methodology. The above analysis was carried out by using the STATGRAPHICS 5 Plus software package version 15.2.11 (StatPoint Technologies, Inc., Warrenton, VA, USA).

The standardized estimated values of main effects, interactions, and second order effects of design factors on the response variables are given in Table 5. Al/CFA factor has the strongest effect on all response variables compared to other design factors. The increase in Al/CFA reduces greatly $d, F_{c}$, $F_{f}$, and $\lambda$ (negative effect) and increases significantly $W_{a}$ (positive effect). CFA/D has a similar effect with $\mathrm{Al} / \mathrm{CFA}$ on $\mathrm{d}, \mathrm{F}_{\mathrm{c}}, \mathrm{F}_{\mathrm{f}}, \mathrm{W}_{\mathrm{a}}$ and $\lambda$; however, its magnitude is considerably lower. On the other hand, the increase in CFA/D increases w/s. SPL has the opposite effect on $d, F_{c}, F_{f}, W_{a}$, and $\lambda$ compared to $\mathrm{CFA} / \mathrm{D}$ and $\mathrm{Al} / \mathrm{CFA}$. With regard to w/s, an increase in SPL causes its countable reduction. Finally, the main effects of RPM on response variables are low and statistically significant only for $\mathrm{d}, \mathrm{w} / \mathrm{s}$, and $W_{\mathrm{a}}$. Several interactions and second order effects also appear statistically significant for all response variables, indicating the non-linear relationship between design factors and response variables.

Table 5. Standardized values of main effects, interactions, and second order effects of design factors on the response variables.

\begin{tabular}{|c|c|c|c|c|c|c|c|c|c|c|c|c|c|c|}
\hline \multirow{2}{*}{$\begin{array}{l}\text { Response } \\
\text { Variable }\end{array}$} & \multicolumn{4}{|c|}{ Main Effects of Design Factors } & \multicolumn{6}{|c|}{ Interactions } & \multicolumn{4}{|c|}{ Second Order Effects } \\
\hline & $\begin{array}{c}\text { A } \\
\text { CFA/D }\end{array}$ & $\begin{array}{c}\text { B } \\
\mathrm{Al} / \mathrm{CFA}\end{array}$ & $\begin{array}{c}\text { C } \\
\text { SPL }\end{array}$ & $\begin{array}{c}\text { D } \\
\text { RPM }\end{array}$ & $\mathbf{A} \times \mathbf{B}$ & $\mathbf{A} \times \mathbf{C}$ & $\mathbf{A} \times \mathbf{D}$ & $\mathbf{B} \times \mathbf{C}$ & $\mathbf{B} \times \mathbf{D}$ & $C \times D$ & $A^{2}$ & $\mathbf{B}^{2}$ & $C^{2}$ & $\mathrm{D}^{2}$ \\
\hline $\mathrm{d}$ & -8.92 & -37.03 & 6.86 & 3.24 & 4.71 & 1.76 & 3.24 & 5.88 & -6.47 & 3.53 & -2.12 & 26.18 & -4.04 & -2.27 \\
\hline $\mathrm{F}_{\mathrm{c}}$ & -4.03 & -67.32 & 8.93 & -0.14 & 7.30 & 1.98 & 1.03 & 3.90 & 2.37 & 3.27 & 1.41 & 54.61 & 1.71 & 2.89 \\
\hline $\mathrm{F}_{\mathrm{f}}$ & -6.42 & -39.98 & 17.27 & 0.18 & 4.30 & 4.40 & 1.05 & -1.50 & -0.20 & 3.90 & -8.25 & 27.72 & -1.07 & -2.62 \\
\hline $\mathrm{W}_{\mathrm{a}}$ & 13.18 & 27.90 & -13.91 & -4.28 & -5.90 & -6.41 & -5.86 & -6.44 & 14.88 & -3.59 & 7.54 & -15.83 & 8.44 & 5.06 \\
\hline$\lambda$ & -9.33 & -21.88 & 5.17 & 1.17 & 8.00 & 0.01 & 1.00 & 2.00 & -4.00 & 1.50 & -0.55 & 17.87 & -0.80 & -2.30 \\
\hline $\mathrm{w} / \mathrm{s}$ & 20.56 & -9.37 & -13.37 & -5.14 & -3.08 & -1.54 & -7.71 & -9.25 & 9.25 & 4.63 & 2.51 & 6.04 & -8.29 & 2.51 \\
\hline
\end{tabular}

The statistically significant factors were selected to develop second order polynomial models linking response variables with factors. The developed models are given in Equations (4)-(9).

$$
\begin{aligned}
& \mathrm{d}=1083.33-374.27 \mathrm{~A}-8407.02 \mathrm{~B}-253.333 \mathrm{C}+0.18 \mathrm{D}-292.40 \mathrm{~A}^{2}+2807.02 \mathrm{AB}+0.10 \mathrm{AD}+ \\
& 54000.00 \mathrm{~B}^{2}+8000.00 \mathrm{BC}-1.1 \mathrm{BD}-2560.0 \mathrm{C}^{2}+0.24 \mathrm{CD}-0.000025 \mathrm{D}^{2}(\mathrm{R}=0.91) \\
& \mathrm{F}_{\mathrm{C}}=20.77-7.01 \mathrm{~A}-220.91 \mathrm{~B}-15.62 \mathrm{C}-0.0025 \mathrm{D}+76.84 \mathrm{AB}+8.35 \mathrm{AC}+684.67 \mathrm{~B}^{2}+93.6 \mathrm{BC} \\
& +0.0065 \mathrm{BD}+0.0039 \mathrm{CD}+2.05 \times 10^{-7} \mathrm{D}^{2}(\mathrm{R}=0.96) \\
& \mathrm{F}_{\mathrm{f}}=4.81+4.33 \mathrm{~A}-107.60 \mathrm{~B}-4.05 \mathrm{C}+0.00073 \mathrm{D}-4.88 \mathrm{~A}^{2}+15.09 \mathrm{AB}+6.18 \mathrm{AC}+564.25 \mathrm{~B}^{2}+ \\
& 0.0016 \mathrm{CD}-1.15 \times 10^{-7} \mathrm{D}^{2}(\mathrm{R}=0.96) \\
& \mathrm{W}_{\mathrm{a}}=38.74+9.73 \mathrm{~A}+106.35 \mathrm{~B}+12.18 \mathrm{C}-0.01 \mathrm{D}+23.21 \mathrm{~A}^{2}-103.51 \mathrm{AB}-44.98 \mathrm{AC}- \\
& 0.0051 \mathrm{AD}-1582.60 \mathrm{~B}^{2}-257.6 \mathrm{BC}+0.074 \mathrm{BD}+135.08 \mathrm{C}^{2}-0.0072 \mathrm{CD}+0.0000013 \mathrm{D}^{2} \\
& (\mathrm{R}=0.95) \\
& \lambda=0.48-0.30 \mathrm{~A}-7.2 \mathrm{~B}+0.13 \mathrm{C}+0.000091 \mathrm{D}+2.81 \mathrm{AB}+36.71 \mathrm{~B}^{2}+1.60 \mathrm{BC}-0.00023 \mathrm{BD}- \\
& 9.97 \times 10^{-9} \mathrm{D}^{2}(\mathrm{R}=0.97) \\
& \mathrm{w} / \mathrm{s}=0.310722+0.252693 \mathrm{~A}-1.04912 \mathrm{~B}-0.0231579 \mathrm{C}-0.0000294737 \mathrm{D}+0.0461681 \mathrm{~A}^{2}- \\
& 0.350877 \mathrm{AB}-0.0701754 \mathrm{AC}-0.0000438596 \mathrm{AD}+2.0 \mathrm{~B}^{2}-2.4 \mathrm{BC}+0.0003 \mathrm{BD}-0.88 \mathrm{C}^{2} \\
& +0.00006 \mathrm{CD}+3.75 \times 10^{-9} \mathrm{D}^{2}(\mathrm{R}=0.90)
\end{aligned}
$$

The estimated regression coefficients $\mathrm{R}$ for the models (4) to (9) varied between 0.90 and 0.97 , indicating that there is a reasonable agreement between predicted and observed values. Thus, the fitted polynomial models describe adequately the influence of the design factors on response variables 
and can be used successfully for the prediction of CMC properties. However, it must be stated that these regression models are accurate and reliable only when the design factors are within the experimentation range.

Figure 10 shows the response surface of density, compressive strength, and water absorption as a function of Al/CFA and CFA/D. SPL and RPM were kept constant at their middle levels. Density and compressive strength indicate similar response surfaces, since they a have strong positive correlation. In contrast, the response surface for water absorption is reversed, since density and water absorption have a strong negative correlation.

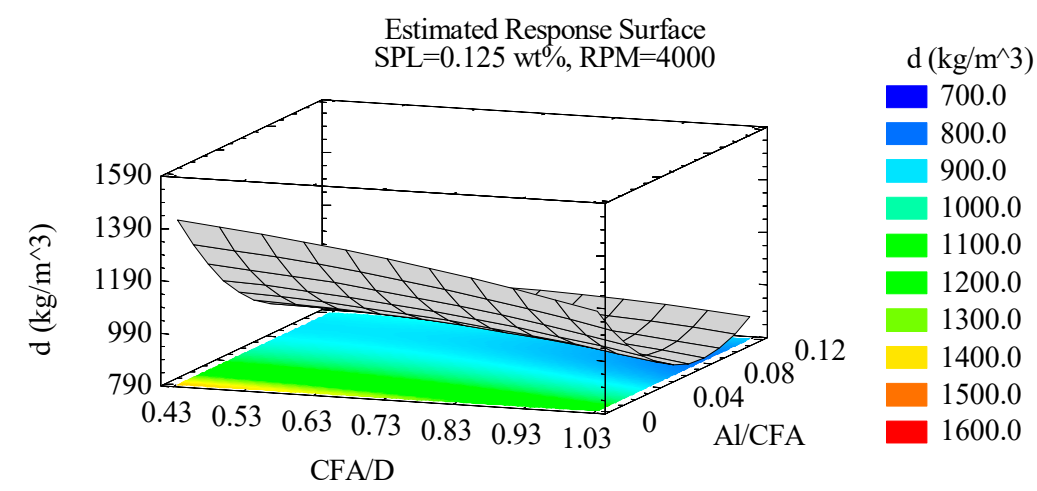

(a)

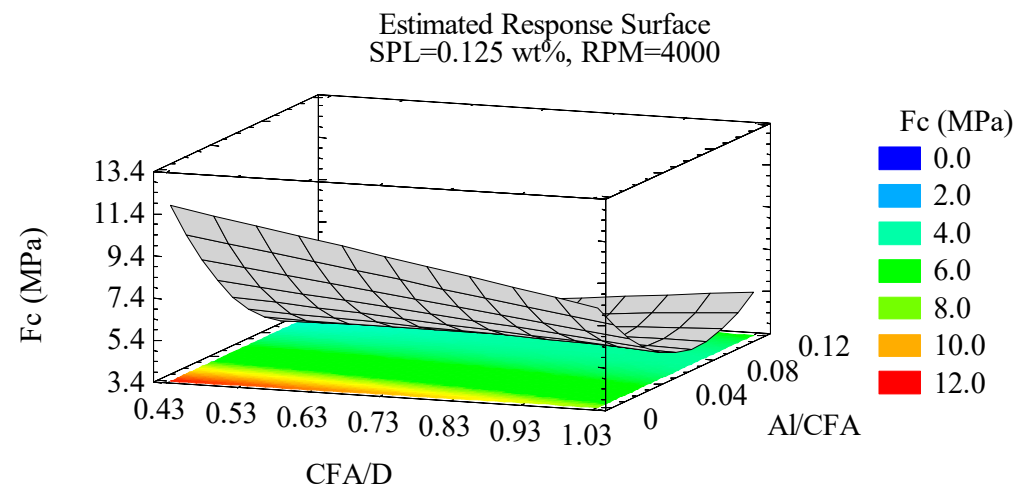

(b)

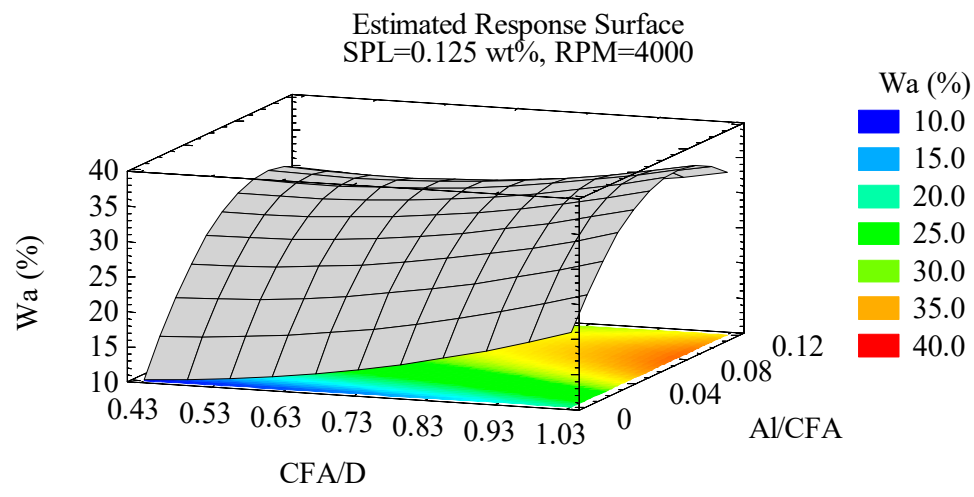

(c)

Figure 10. Plots of response surfaces of (a) density; (b) compressive strength; (c) water absorption, as function of the design factors CFA/D and Al/CFA. SPL and RPM are kept constant at their middle levels. 
Polynomial models developed above (4)-(9) allow the design of mixtures with predefined and/or optimized values of physical and mechanical properties of the produced CMC by using the multiple response optimization method developed by Myers and Montgomery, [33].

In this study, three different optimization cases were examined. In the first and second case, the goal of the optimization was to maximize the compressive strength for predefined values for density $\left(\mathrm{d}=700 \mathrm{~kg} / \mathrm{m}^{3}\right.$ and $\left.\mathrm{d}=800 \mathrm{~kg} / \mathrm{m}^{3}\right)$. In the third case, the goal was to minimize density and to maximize compressive strength simultaneously. Based on the optimum design factors corresponding to each optimization case, CMC specimens were produced and tested for their compressive strength and density. The optimization results are given in Table 6. As seen in Table 6, measured values validate the design methodology since the differences between designed and measured values are in the range of measurement error ( $0.5 \mathrm{MPa}$ for $\mathrm{F}_{\mathrm{c}}$ and $17 \mathrm{~kg} / \mathrm{m}^{3}$ for $\left.\mathrm{d}\right)$.

Table 6. Optimization results.

\begin{tabular}{|c|c|c|c|c|c|c|c|c|c|}
\hline \multirow{2}{*}{ No. } & \multirow{2}{*}{$\begin{array}{c}\text { Optimization } \\
\text { Goal }\end{array}$} & \multicolumn{4}{|c|}{ Optimum Values for Factors } & \multicolumn{2}{|c|}{ Predicted } & \multicolumn{2}{|c|}{ Measured } \\
\hline & & CFA/D & Al/CFA & SPL & RPM & $\mathrm{d}\left(\mathrm{kg} / \mathrm{m}^{3}\right)$ & $\mathrm{F}_{\mathrm{c}}(\mathrm{MPa})$ & $\mathrm{d}\left(\mathrm{kg} / \mathrm{m}^{3}\right)$ & $\mathrm{F}_{\mathrm{c}}(\mathrm{MPa})$ \\
\hline 1 & $\begin{array}{c}\mathrm{d}=700 \mathrm{~kg} / \mathrm{m}^{3} \& \\
\mathrm{~F}_{\mathrm{C}}=\max \end{array}$ & 1.000 & 0.057 & 0.000 & 3000 & 700 & 3.4 & 715 & 3.8 \\
\hline 2 & $\begin{array}{c}\mathrm{d}=800 \mathrm{~kg} / \mathrm{m}^{3} \& \\
\mathrm{~F}_{\mathrm{C}}=\max \end{array}$ & 1.000 & 0.042 & 0.076 & 3000 & 800 & 4.9 & 810 & 5.2 \\
\hline 3 & $\begin{array}{c}\mathrm{d}=\min \& \\
\mathrm{~F}_{\mathrm{C}}=\max \end{array}$ & 1.000 & 0.036 & 0.250 & 3000 & 813 & 6.6 & 830 & 7.1 \\
\hline
\end{tabular}

\subsection{Comparison with Previous Studies}

For the comparison of the properties of the produced cellular micro-concrete specimens with those obtained in previous studies, the strength-to-density ratio $\left(F_{c} / d\right)$ was used. Table 7 shows the $\mathrm{F}_{\mathrm{c}} / \mathrm{d}$ obtained in this study and those derived from other selected studies regarding the production of moist-cured cellular concrete $\left(20 \pm 2{ }^{\circ} \mathrm{C}\right.$ and at least $90 \%$ relative humidity for 28 days), with density values ranging between 400 and $1300 \mathrm{~kg} / \mathrm{m}^{3}$. As seen in Table 7 , research studies regarding the production of moist-cured cellular concrete using aluminum powder as an aerating agent are limited.

Table 7. Comparison of compressive strength-to-density ratio $\left(\mathrm{F}_{\mathrm{c}} / \mathrm{d}\right)$ for moist-cured cellular concrete.

\begin{tabular}{|c|c|c|c|c|}
\hline Raw Materials & $\begin{array}{l}\text { Aerating } \\
\text { Agent }\end{array}$ & $\begin{array}{c}\text { Compressive } \\
\text { Strength-to-Density } \\
\text { Ratio, } \mathrm{F}_{\mathrm{c}} / \mathrm{d} \\
\left(\left[\mathrm{MPa} /\left(\mathrm{kg} / \mathrm{m}^{3}\right)\right] \times \mathbf{1 0}^{-3}\right)\end{array}$ & $\begin{array}{l}\text { Density } \\
\left(\mathrm{kg} / \mathrm{m}^{3}\right)\end{array}$ & Reference \\
\hline $\begin{array}{c}\text { Clayey fines } \\
\text { (kaolinites), CEM I } \\
52.5 \mathrm{~N}\end{array}$ & $\begin{array}{l}\text { Aluminum } \\
\text { powder }\end{array}$ & $1.1-3.7$ & $850-1050$ & Goual et al. [36] \\
\hline $\begin{array}{l}\text { River sand, } \\
\text { Portland Pozzolana } \\
\text { Cement (PPC) }\end{array}$ & $\begin{array}{l}\text { Aluminum } \\
\text { powder }\end{array}$ & $0.6-8.3$ & $450-1250$ & $\begin{array}{c}\text { Kumar and } \\
\text { Ramamurthy [37] }\end{array}$ \\
\hline $\begin{array}{l}\text { Quarry dust, } \\
\text { CEM I 52.5N }\end{array}$ & $\begin{array}{l}\text { Sodium lauryl } \\
\text { sulphate }\end{array}$ & $9.0-10.3$ & $800-1200$ & Tharakarama et al. [38] \\
\hline $\begin{array}{l}\text { River sand, } \\
\text { siliceous fly ash, } \\
\text { gypsum, } \\
\text { granulated blast } \\
\text { furnace slag, } \\
\text { CEM II 42.5R }\end{array}$ & $\begin{array}{l}\text { Protein-based } \\
\text { agent }\end{array}$ & $1.0-1.4$ & 920-1130 & Oren et al. [39] \\
\hline $\begin{array}{l}\text { Quarry dust, } \\
\text { calcareous fly ash, } \\
\text { CEM I } 42.5 \mathrm{~N}\end{array}$ & $\begin{array}{l}\text { Aluminum } \\
\text { powder }\end{array}$ & $2.8-6.5$ & $680-1080$ & Present study \\
\hline
\end{tabular}


In this study, the acquired $\mathrm{F}_{\mathrm{c}} / \mathrm{d}$ and density values of cellular concrete produced with quarry dust, calcareous fly ash, CEM I $42.5 \mathrm{~N}$, and aluminum powder as an aerating agent, ranged between 2.8 and $6.5\left(\left[\mathrm{MPa} /\left(\mathrm{kg} / \mathrm{m}^{3}\right)\right] \times 10^{-3}\right)$ and $680-1080 \mathrm{~kg} / \mathrm{m}^{3}$, respectively.

Based on $\mathrm{F}_{\mathrm{c}} / \mathrm{d}$ ratio, the moist-cured cellular concrete prepared in this study outperforms most of those presented in Table 7 . There are some cases where $\mathrm{F}_{\mathrm{c}} / \mathrm{d}$ ratio exceeds the one calculated in this study; however, it must be noted that, in these cases, the examined cellular concrete products had density values as high as $1200-1250 \mathrm{~kg} / \mathrm{m}^{3}$, while in parallel, a high-strength cement (CEM I 52.5N) was used for their preparation.

\section{Conclusions}

The factorial design results indicated that the aerating agent to cement and fly ash ratio has a significant effect on the density of the hardened specimens, which is a physical property of great importance since it strongly affects all the measured properties (compressive and flexural strength, water absorption, and thermal conductivity). Moreover, the results showed that cement and fly ash to quarry dust ratio has a similar effect with aerating agent to cement and fly ash ratio on response variables. Superplasticizer dosage has the opposite effect on response variables compared to aerating agent to cement and fly ash ratio and cement and fly ash to quarry dust ratio, whereas the effect of mixer speed (revolutions per minute) on response variables is low and statistically significant only for density, water absorption, and water-to-solids ratio.

The developed polynomial models describe adequately the non-linear influence of the design factors on response variables and can be used successfully for the prediction of cellular micro-concrete properties; however, the developed regression models are accurate and reliable only when the design factors are within the experimentation range. In this way, regarding the optimization results, the measured values validated the design methodology. Since factorial design of experiments and the response surface methodology have been successfully used for product design and improvement in several industrial applications, we consider that the proposed mixture design methodology could be used at industrial scale. However, with regard to the required long curing time, industrial-scale applications would demand large CMC curing installations and additional costs. However, the additional costs could be compensated by the lower energy required (compared to energy-intensive hydrothermal curing process).

Concerning the comparison between the existing studies and the current study, it should be mentioned that the prepared cellular micro-concrete, which utilizes a large amount of quarry dust (around $50 \%$ to $70 \%$ ), outperforms most of the examined similar cellular concrete products.

Finally, besides CMC conventional moist-curing, the production of low-density CMC using rapid curing techniques in a $\mathrm{CO}_{2}$ environment so as to accelerate hardening, improve physical-mechanical properties, and mitigate the environmental impact is under investigation for possible applications.

Author Contributions: Conceptualization, M.G.; Formal analysis, A.S. and M.G.; Investigation, A.S.; Methodology, M.G.; Supervision, M.G.; Writing-original draft, A.S.; Writing-review \& editing, M.G. All authors have read and agreed to the published version of the manuscript.

Funding: This research received no external funding.

Acknowledgments: This work was performed under the framework of the project "National Contribution to European competitive projects-BEWEXMIN" (82287) managed by the Research Committee of the Technical University of Crete.

Conflicts of Interest: The authors declare no conflict of interest.

\section{References}

1. Galetakis, M.; Alevizos, G.; Leventakis, K. Evaluation of fine limestone quarry by-products, for the production of building elements-An experimental approach. Constr. Build. Mater. 2012, 26, 122-130. [CrossRef]

2. Sairanen, M.; Rinne, M.; Selonen, O. A review of dust emission dispersions in rock aggregate and natural stone quarries. Int. J. Min. Reclam. Environ. 2018, 32, 196-220. [CrossRef] 
3. Yang, R.; Yu, R.; Shui, Z.; Gao, X.; Han, J.; Lin, G.; Qian, D.; Liu, Z.; He, Y. Environmental and economical friendly ultra-high performance-concrete incorporating appropriate quarry-stone powders. J. Clean. Prod. 2020, 260, 121112. [CrossRef]

4. Manca, P.P.; Orrù, G.; Desogus, P. Recycling of sludge from ornamental stone processing as resource in civil constructions. Int. J. Min. Reclam. Environ. 2015, 29, 141-155. [CrossRef]

5. Arunachalam, N.; Mahesh, V.; Dileepkumar, P.; Sounder, V. Development of innovative building blocks. J. Mech. Civ. Eng. 2014, 1-7. Available online: https://www.iosrjournals.org/iosr-jmce/papers/ICRTEM/CE/ IOSRCE004.pdf (accessed on 23 November 2020).

6. Lim, S.K.; Tan, C.S.; Li, B.; Ling, T.C.; Hossain, U.; Poon, C.S. Utilizing high volumes quarry wastes in the production of lightweight foamed concrete. Constr. Build. Mater. 2017, 151, 441-448. [CrossRef]

7. Rana, A.; Kalla, P.; Csetenyi, L.J. Recycling of dimension limestone industry waste in concrete. Int. J. Min. Reclam. Environ. 2017, 31, 231-250. [CrossRef]

8. Galetakis, M.; Soultana, A. A review on the utilization of quarry and ornamental stone industry fine by-products in the construction sector. Constr. Build. Mater. 2016, 102, 769-781. [CrossRef]

9. Algin, H.M.; Turgut, P. Cotton and limestone powder wastes as brick material. Constr. Build. Mater. 2008, 22, 1074-1080. [CrossRef]

10. Turgut, P. Masonry composite material made of limestone powder and fly ash. Powder Technol. 2010, 204, 42-47. [CrossRef]

11. Almeida, N.; Branco, F.; De Brito, J.; Santos, J.R. High-performance concrete with recycled stone slurry. Cem. Concr. Res. 2007, 37, 210-220. [CrossRef]

12. Gesoglu, M.; Güneyisi, E.; Kocabag, M.E.; Bayram, V.; Mermerdas, K. Fresh and hardened characteristics of self-compacting concretes made with combined use of marble powder, limestone filler, and fly ash. Constr. Build. Mater. 2012, 37, 160-170. [CrossRef]

13. Courard, L.; Michel, F.; Pierard, J. Influence of clay in limestone fillers for self-compacting cement-based composites. Constr. Build. Mater. 2011, 25, 1356-1361. [CrossRef]

14. Dehwah, H.A.F. Mechanical properties of self-compacting concrete incorporating quarry dust powder, silica fume or fly ash. Constr. Build. Mater. 2012, 26, 547-551. [CrossRef]

15. Katz, A.; Baum, H. Effect of high levels of fines content on concrete properties. ACI Mater. J. 2006, 103, 474-482.

16. Hamad, A.J. Materials, Production, Properties and application of aerated lightweight concrete: Review. Int. J. Mater. Sci. Eng. 2014, 2, 152-157. [CrossRef]

17. Kanehira, S.; Kanamori, S.; Nagashima, K.; Saeki, T.; Visbal, H.; Fukui, T.; Hirao, K. Controllable hydrogen release via aluminum powder corrosion in calcium hydroxide solutions. J. Am. Ceram. Soc. 2013, 1, $296-303$. [CrossRef]

18. Normohammadi, M.; Kakooei, H.; Omidi, L.; Yari, S.; Alimi, R. Risk assessment of exposure to silica dust in building demolition sites. Saf. Health Work. 2016, 7, 251-255. [CrossRef]

19. Rashad, A.M. A brief on high-volume Class F fly ash as cement replacement-A guide for Civil Engineer. Int. J. Sustain. Built Environ. 2015, 4, 278-306. [CrossRef]

20. Wang, J.; Wang, Y.; Sun, Y.; Tingley, D.D.; Zhang, Y.R. Life cycle sustainability assessment of fly ash concrete structures. Renew. Sust. Energy Rev. 2017, 80, 1162-1174. [CrossRef]

21. Turgut, P. Manufacturing of building bricks without Portland cement. J. Clean. Prod. 2012, 37, 361-367. [CrossRef]

22. Sumer, M. Compressive strength and sulfate resistance properties of concretes containing Class F and Class C fly ashes. Constr. Build. Mater. 2012, 34, 531-536. [CrossRef]

23. Uysal, M.; Akyuncu, V. Durability performance of concrete incorporating Class F and Class C fly ash. Constr. Build. Mater. 2012, 34, 170-178. [CrossRef]

24. Somanchi, S.; Kecojevic, V.J.; Bise, C.J. Analysis of force variance for a continuous miner drum using the Design of Experiments method. Int. J. Min. Reclam. Environ. 2006, 20, 111-126. [CrossRef]

25. Santilli, A.; Puente, I.; Tanco, M. A factorial design study to determine the significant parameters of fresh concrete lateral pressure and initial rate of pressure decay. Constr. Build. Mater. 2011, 25, 1946-1955. [CrossRef]

26. López-Gayarre, F.; López-Colina, C.; Serrano-López, M.A.; García-Taengua, E.; López-Martínez, A. Assessment of properties of recycled concrete by means of a highly fractioned factorial design of experiment. Constr. Build. Mater. 2011, 25, 3802-3809. [CrossRef] 
27. Kioupis, D.; Kavakakis, C.; Tsivilis, S.; Kakali, G. Synthesis and characterization of porous fly ash-based geopolymers using Si as foaming agent. Adv. Mater. Sci. Eng. 2018, 1942898. [CrossRef]

28. Mermerdas, K.; Algın, Z.; Ekmen, Ş. Experimental assessment and optimization of mix parameters of fly ash-based lightweight geopolymer mortar with respect to shrinkage and strength. J. Build. Eng. 2020, 31, 101351. [CrossRef]

29. Ferreira, S.L.C.; Bruns, R.E.; Ferreira, H.S.; Matos, G.D.; David, J.M.; Brandao, G.C.; da Silva, E.G.P.; Portugal, L.A.; dos Reis, P.S.; Souza, A.S.; et al. Box-Behnken design: An alternative for the optimization of analytical methods. Anal. Chim. Acta 2007, 597, 179-186. [CrossRef]

30. Montgomery, D.C. Design and Analysis of Experiments; John Wiley \& Sons: New York, NY, USA, 2001.

31. Galetakis, M.; Piperidi, C.; Alevizos, G.; Stiakakis, E.; Komnitsas, K.; Soultana, A.; Vasileiou, A. Experimental investigation of the utilization of quarry dust for the production of microcement-based building elements by moulding casting. Constr. Build. Mater. 2016, 107, 247-254. [CrossRef]

32. Prasittisopin, L.; Trejo, D. Effects of mixing variables on hardened characteristics of Portland cement mortars. ACI Mater. J. 2014, 111, 1-6. [CrossRef]

33. Myers, R.H.; Montgomery, D.C. Response Surface Methodology: Product and Process Optimization Using Designed Experiments, 2nd ed.; John Wiley \& Sons: New York, NY, USA, 2002.

34. Box, G.E.P.; Draper, N.R. Wiley Series in Probability and Mathematical Statistics. In Empirical Model-Building and Response Surfaces; John Wiley \& Sons: New York, NY, USA, 1987.

35. Zhao, D.; Qian, X.; Gu, X.; Jajja, S.A.; Yang, R. Measurement techniques for thermal conductivity and interfacial thermal conductance of bulk and thin film materials. J. Electron. Packag. 2016, 138, 040802. [CrossRef]

36. Goual, M.S.; Bali, A.; de Barquin, F.; Dheilly, R.M.; Quéneudec, M. Isothermal moisture properties of clayey cellular concretes elaborated from clayey waste, cement and aluminum powder. Cem. Concr. Res. 2006, 36, 1768-1776. [CrossRef]

37. Kumar, E.M.; Ramamurthy, K. Effect of fineness and dosage of aluminum powder on the properties of moist-cured aerated concrete. Constr. Build. Mater. 2015, 95, 486-496. [CrossRef]

38. Tharakarama, T.; Veni, B.; Krishna, P.B. An experimental investigation on light weight foam cement blocks with quarry dust replacement for fine aggregate. Int. Res. J. Eng. Technol. 2017, 4, 844-850.

39. Oren, O.H.; Gholampour, A.; Gencel, O.; Ozbakkaloglu, T. Physical and mechanical properties of foam concretes containing granulated blast furnace slag as fine aggregate. Constr. Build. Mater. 2020, 238, 117774. [CrossRef]

40. Chung, S.Y.; Lehmann, C.; Elrahman, M.A.; Stephan, D. Pore characteristics and their effects on the material properties of foamed concrete evaluated using micro-CT images and numerical approaches. Appl. Sci. 2017, 7, 550. [CrossRef]

41. Mydin, M.O.; Wang, Y.C. Mechanical properties of foamed concrete exposed to high temperatures. Constr. Build. Mater. 2012, 26, 638-654. [CrossRef]

42. Galetakis, M.; Roumpos, C. A multi-objective response surface analysis for the determination of the optimal cut-off quality and minimum thickness for selective mining of multiple-layered lignite deposits. Energy Sour. Part A Recover. Util. Environ. Eff. 2015, 37, 428-439. [CrossRef]

43. Vamvuka, D.; Galetakis, M.; Merkoulidi, G. Investigation of the combustion performance of residues from vineyards and processing industry via fluidized bed experiments, factorial design and modeling. Combust. Sci. Technol. 2016, 189, 890-907. [CrossRef]

Publisher's Note: MDPI stays neutral with regard to jurisdictional claims in published maps and institutional affiliations.

(C) 2020 by the authors. Licensee MDPI, Basel, Switzerland. This article is an open access article distributed under the terms and conditions of the Creative Commons Attribution (CC BY) license (http://creativecommons.org/licenses/by/4.0/). 